\title{
Pembelajaran Kooperatif Think Pair Share Menggunakan Assessment for Learning Pada Prestasi Analisis Real Mahasiswa
}

\author{
Oki Ribut Yuda Pradana \\ Program Studi Pendidikan Matematika, STKIP Modern Ngawi \\ E-mail: Okirbt@gmail.com
}

\begin{abstract}
Abstrak
Analisis Real adalah salah satu mata kuliah wajib pada program studi pendidikan matematika strata satu. Banyak mahasiswa yang cenderung mengalami kesulitan dalam memahami materi pada mata kuliah ini dibuktikan dengan hasil belajar yang rendah. Maka dari itu, salah satu solusi yang diajukan agar mahasiswa mudah memahami mata kuliah ini adalah implementasi pembelajaran Kooperatif Think Pair Share. Tujuan penelitian ini adalah mengetahui pengaruh pembelajaran Kooperatif Think Pair Share menggunakan assessment for learning pada prestasi Analisis Real mahasiswa. Metode penelitian ini adalah eksperimentasi kuantitatif. Hasil penelitian ini menunjukkan adanya pengaruh positif dari model pembelajaran Kooperatif Think Pair Share terhadap pretasi Analisis Real mahasiswa. Model pembelajaran ini bisa dijadikan salah satu referensi untuk mengatasi masalah rendahnya prestasi mahasiswa di semua mata kuliah. Berdasarkan hal tersebut, penelitian lanjutan sangat dibutuhkan.
\end{abstract}

Kata Kunci:, Analisis Real, Assessment for Learning, Think Pair Share, Prestasi

\section{PENDAHULUAN}

Analisis Real adalah salah satu mata kuliah wajib pada program studi pendidikan matematika strata satu. Banyak mahasiswa yang tidak memahami materi ini. Berdasarkan hasil wawancara dengan beberapa mahasiswa, banyak mahasiswa mengalami kesulitan dalam pembuktian matematis di beberapa mata kuliah analisis, salah satunya adalah pembuktian pada mata kuliah analisis real, bahkan hampir semua mahasiswa mengalami kesulitan dalam belajar Analisis Real. Hal ini sejalan dengan penelitian Nurul Imamah tahun 2016.

Mata kuliah ini didasari oleh logika. Jika mahasiswa gagal memahami mata kuliah ini, maka ada yang salah dengan cara mereka berlogika. Hal ini harus segera diatasi karena banyak mata kuliah di program studi ini yang melibatkan kemampuan berlogika.

Dosen memiliki peran penting dalam proses pembelajaran. Dosen seharusnya meningkatkan kualitas diri dalam mengajar, khususnya pada mata kuliah analisis. Peran dosen dalam mengembangkan suasana akademik yang kondusif adalah sangat penting sehingga dosen perlu didorong untuk terus aktif dan inovatif dalam menggali ide-ide baru.

Tsay dan Brady (2010) menemukan bahwa ada hubungan positif antara pembelajaran kooperatif dan kinerja akademik, serta kemampuan siswa dalam berkomunikasi. Di sisi lain, Penilaian mungkin adalah hal paling penting yang dapat kita lakukan untuk membantu siswa kita belajar (Brown: 2004). Hal ini berarti penilaian menjadi hal penting untuk membantu siswa belajar, sehingga fungsi penilaian tidak hanya digunakan untuk menilai siswa tapi juga untuk pembelajaran mereka. Dalam hal ini, penilaian yang cocok digunakan adalah Asessment for Learning.

Penelitian Pradana, Mashuri, dan Nirawati (2019) menyimpulkan pembelajaran kooperatif Think Pair Share menggunakan Assessment for Learning memberikan hasil positif dalam meningkatkan prestasi belajar matematika. Hal ini sejalan dengan pendapat Slavin (1990) yang menyatakan bahwa upaya kooperatif antar siswa dapat meningkatkan prestasi yang lebih tingg. Lebih lanjut Pradana, Mashuri, dan Nirawati 
(2019) menjelaskan langkah-langkah pembelajaran Think Pair Share menggunakan Assessment for Learning sebagai berikut.

Tabel 1. Langkah-langkah Pembelajaran Think Pair Share menggunakan Assessment for Learning

\begin{tabular}{|c|c|}
\hline Langkah & Aktivitas \\
\hline Pembukaan & $\begin{array}{l}\text { Dosen melakukan apersepsi, } \\
\text { menjelaskan tujuan pelajaran, } \\
\text { menyampaikan materi, dan } \\
\text { menghubungkan materi sebelumnya } \\
\text { dengan materi yang akan dipelajari. }\end{array}$ \\
\hline Think & $\begin{array}{l}\text { Mahasiswa memikirkan pertanyaan } \\
\text { dosen secara individual. Kemudian, } \\
\text { Mahasiswa yang berhasil menyelesai- } \\
\text { kan masalah berhak mendapatkan } \\
\text { tanda keberhasilan dari dosen }\end{array}$ \\
\hline Pair & $\begin{array}{l}\text { Mahasiswa yang gagal berpasangan } \\
\text { dengan teman dan berdiskusi. } \\
\text { Selanjutnya, setiap mahasiswa yang } \\
\text { sebelumnya menerima tanda } \\
\text { keberhasilan ditugaskan untuk } \\
\text { menjadi ketua di masing- masing } \\
\text { kelompok untuk memandu diskusi } \\
\text { dan berhak untuk juga memberikan } \\
\text { tanda keberhasilan bagi kelompok } \\
\text { yang berhasil memecahkan masalah. }\end{array}$ \\
\hline Share & $\begin{array}{l}\text { Perwakilan kelompok mempresenta- } \\
\text { sikan jawaban mereka di depan kelas. } \\
\text { Selanjutnya, baik mahasiswa lainnya } \\
\text { dan dosen memberikan umpan balik } \\
\text { pada jawabannya. }\end{array}$ \\
\hline Penutup & $\begin{array}{l}\text { Dosen dengan mahasiswa melakukan } \\
\text { refleksi. Dosen memberikan umpan } \\
\text { balik tentang proses dan hasil } \\
\text { pembelajaran. Dosen memberikan } \\
\text { pekerjaan rumah dan menginforma- } \\
\text { sikan materi pembelajaran untuk } \\
\text { pertemuan berikutnya. }\end{array}$ \\
\hline
\end{tabular}

\section{METODE}

Jenis penelitian yang digunakan adalah kuasi eksperimental. Populasi penelitian ini adalah seluruh mahasiswa program studi pendidikan matematika se-Karesidenan Madiun yang telah mendapatkan materi Analisis Real.

Teknik pengambilan sampel dilakukan dengan cara Cluster Random Sampling.
Populasi dikelompokkan berdasarkan kelas di perguruan tinggi masing-masing dan diambil secara acak satu kelas. Berdasarkan teknik tersebut diperoleh sampel satu kelas di STKIP Modern Ngawi. Kelas tersebut adalah mahasiswa program studi Pendidikan Matematika semester 6 STKIP modern Ngawi 2020/2021 yang berjumlah 32 mahasiswa.

Sampel tersebut dibagi menjadi dua kelompok. Kelompok A sebagai kelas kontrol dengan jumlah 16 mahasiswa dan Kelompok B ditetapkan sebagai kelas eksperimen dengan jumlah 16 mahasiswa. Kelompok A diberi pembelajaran konvensional sedangkan kelompok B diberi pembelajaran Think Pair Share berbasis Assessment for Learning. Penelitian ini dilakukan dalam waktu satu bulan atau empat kali tatap muka. Masing-masing kelompok dibuat kategori kemampuan tinggi, rendah, dan sedang.

Variabel dalam penelitian ini adalah variabel bebas dan variabel terikat. Variabel bebas dalam penelitian ini adalah model pembelajaran sedangkan variabel terikatnya adalah prestasi Analisis Real mahasiswa pada materi limit barisan. Metode pengumpulan data yang digunakan adalah metode tes. Metode tes digunakan untuk memperoleh data kemampuan awal dan hasil perlakuan.

Hasil tes kemampuan awal digunakan untuk mengetahui normalitas, homogenitas, dan keseimbangan kelompok. Budiono (2016: 174) mengatakan bahwa uji normalitas digunakan untuk mengetahui apakah data berdistribusi normal atau tidak. Uji homogenitas digunakan untuk mengetahui apakah variansi kedua kelompok tersebut sama atau tidak. Uji keseimbangan digunakan untuk mengetahui apakah kedua kelompok memiliki kemampuan yang sama atau tidak. Uji normalitas menggunakan metode Liliefors. Uji homogenitas menggunakan metode Bartlet. Selanjutnya, uji keseimbangan menggunakan Anava. Data hasil perlakuan digunakan untuk 
mengetahui apakah pembelajaran Think Pair Share berbasis Assessment for Learning memberikan hasil yang sama atau tidak dengan pembelajaran konvensional serta mana yang lebih baik hasilnya. Metode yang digunakan untuk mengetahuinya adalah uji Anava satu jalan sel sama.

\section{HASIL DAN PEMBAHASAN}

Dari data hasil tes kemampuan awal mahasiswa diperoleh hasil uji normalitas dengan taraf signifikasi $\alpha=5 \%$ yang menyimpulkan bahwa data dari kedua kelompok berdistribusi normal. Hal ini ditunjukkan $L_{o b s}<L_{\text {tabel }}$. Selanjutnya, hasil uji normalitas dirangkum dalam tabel 2 berikut.

Tabel 2. Hasil Uji Normalitas

\begin{tabular}{|c|c|c|c|c|}
\hline Kelompok & $N$ & $L_{\text {obs }}$ & $L_{\text {tabel }}$ & Kesimpulan \\
\hline A & 16 & 0,132 & 0,213 & Normal \\
\hline B & 16 & 0,142 & 0,213 & Normal \\
\hline
\end{tabular}

Selanjutnya hasil uji Homogenitas menggunakan uji Bartlett dengan taraf signifikasi 5\% diperoleh kedua kelompok memiliki variansi yang sama (Homogen). Hal ini ditunjukkan $X^{2}{ }_{\text {obs }}<X_{\text {tabel. }}^{2}$ Hasil uji Homogenitas dirangkum dalam tabel 3 berikut.

Tabel 3. Hasil Uji Homogenitas

\begin{tabular}{|l|l|l|l|l|}
\hline Kelompok & $K$ & $X^{2}{ }_{\text {obs }}$ & $X_{\text {tabel }}^{2}$ & Kesimpulan \\
\hline A dan B & 2 & 2,564 & 3,841 & Homogen \\
\hline
\end{tabular}

Hasil uji keseimbangan antara kelompok A dan B dengan Anava dan taraf signifikasi 5\% dirangkum dalam tabel 4 berikut.

Tabel 4. Hasil Uji Keseimbangan

\begin{tabular}{|l|c|l|l|l|l|}
\hline & $J K$ & $d k$ & $R K$ & $F_{\text {obs }}$ & $F_{\text {tabel }}$ \\
\hline Kelompok & 25901,91 & 1 & 25901,91 & 4,03 & 4,15 \\
\hline Galat & 199023,01 & 31 & 6420,09 & & \\
\hline Total & 19082,92 & 32 & & & \\
\hline
\end{tabular}

Dari tabel 4 diperoleh $F_{o b s}<F_{\text {Tabel }}$. Hal ini dapat disimpulkan bahwa kedua kelompok dalam keadaan seimbang.
Data hasil perlakuan dirangkum dalam tabel 5 berikut.

Tabel 5. Hasil Tes Perlakuan

\begin{tabular}{|l|l|l|l|l|}
\hline & $N$ & $x_{\min }$ & $x_{\text {maks }}$ & Rata-rata \\
\hline Kelompok A & 16 & 55,76 & 82,32 & 63,21 \\
\hline Kelompok B & 16 & 67,32 & 87,91 & 80,43 \\
\hline
\end{tabular}

Selanjutnya, hasil perhitungan analisis variansi satu jalan sel sama dengan taraf signifikasi $\alpha=5 \%$ disajikan dalam tabel 6 berikut.

Tabel 6. Hasil Uji ANAVA

\begin{tabular}{|l|c|l|l|l|l|}
\hline & $J K$ & $d k$ & $R K$ & $F_{\text {obs }}$ & $F_{\text {tabel }}$ \\
\hline Model & 6701,31 & 1 & 67,31 & 17,21 & 4,15 \\
\hline Galat & 121,02 & 31 & 3,91 & & \\
\hline Total & 188,33 & 32 & & & \\
\hline
\end{tabular}

Berdasarkan tabel 5 di atas dapat dilihat bahwa $F_{o b s}>F_{\text {Tabel }}$ yang artinya kedua model pembelajaran memberikan hasil yang berbeda. Berdasarkan tabel 5, dapat diketahui bahwa nilai rata-rata kelompok $\mathrm{B}$ lebih besar daripada kelompok A.

Hal ini berarti kelompok dengan pembelajaran Think Pair Share berbasis Assessment for Learning memiliki prestasi lebih baik daripada kelompok dengan model pembelajaran konvensional.

Hasil ini sejalan dengan penelitian Pradana, Mashuri, dan Nirawati (2019) yang menyimpulkan bahwa pembelajaran Think Pair Share berbasis Assessment for Learning memberikan hasil yang lebih baik dari pembelajaran konvensional. Barkaitan dengan Think Pair Share, hasil ini juga sejalan dengan penelitian Ribut (2021).

Hal ini disebabkan karena penggunaan assessment yang tepat dapat membuat pembelajaran lebih efektif. Jones (2005: 5) mengatakan bahwa Assessment for Learning is all about informing learners of their progress to empower them to take the necessary action to improve their performance. Lebih lanjut Cambridge Assessment International Education menyatakan Peer feedback can only take place 
when learners have a clear idea about what they are discussing and the areas that they should (and should not) be giving feedback about.

Di sisi lain adanya Di sisi lain adanya. Di sisi lain adanya umpan balik dari teman membantu mahasiswa dalam memahami materi. Hal ini sejalan dengan pendapat Spiller (2009: 12) bahwa peer assessment processes can help students learn how to receive and give feedback which is an important part of most work contexts. Mahasiswa juga akan termotivasi untuk mendapat tanda sukses dari teman mereka yang sudah berhasil mendapatkannya lebih dulu.

\section{PENUTUP}

\section{Simpulan}

Temuan penelitian ini adalah Think Pair Share dengan assessment for learning lebih berpotensi untuk meningkatkan prestasi Analisis Real mahasiswa daripada model pembelajaran konvensional pada materi limit barisan.

\section{Saran}

Bagi para dosen sebaiknya model pembelajaran ini dijadikan referensi untuk proses pembelajaran. Bagi peneliti lain dalam melakukan penelitian yang serupa sebaiknya penelitian dilakukan dengan mengubah materi pembelajaran. Jika memberikan efek positif, maka pembelajaran ini bisa menjadi solusi bagi semua praktisi pendidikan.

\section{DAFTAR PUSTAKA}

Budiono. (2016). Statistika Untuk Penelitian. Surakarta: UNS Press.

Brown, S. (2004). Learning and Teaching in Higher Education. International Journal Issue 1, 81-88.

Imamah, Nurul. (2016). Pengembangan Bahan Ajar Mata Kuliah Analisis Real Berbasis Pembuktian Pada Semester V UNMUH Jember. Jurnal Gammath, 1(2), 26-32.

Jones, Cheryl. (2005). Assessment for Learning. London: Learning and Skills Development Agency.
Pradana, O. R. Y., Mashuri, A., \& Nirawati, L. S. (2019). Pengaruh Model Pembelajaran Kooperatif Think Pair Share (TPS) Menggunakan Assessment For Learning Pada Prestasi Siswa Sekolah Menengah Pertama. Jurnal Karya Pendidikan Matematika, 6(2), 34-40.

Ribut, O. (2021). Pengaruh Model Pembelajaran Kooperatif Think Pair Share (TPS) Pada Prestasi matematika Siswa Sekolah Menengah Pertama. Jurnal Jendela Pendidikan, 1(1), 1-6.

Slavin. (1990). Cooperative learning: Theory, research and practice. Massachussetts: Simon \& Schuster Inc.

Spiller, D. (2009). Assessment Matters: Selfassessment and Peer Assessment. Nova Zelândia: Universidade de Waikato.

Tsay, M. dan Brady, M. (2010). A case study of cooperative and communication pedagogy. Journal of the Scholarship of Teaching and Learning, 10, 78-89.

https://www.cambridge-community.org.uk/pro fessional-development/gswafl/index.html. 